She plans on trying to keep pigeons again though.

Gordon Orenchuk has observed that a mother pigeon seems to know when the young are big enough to be pushed out of the nest. Why not tell us how the mother goes about doing this, Gordon, and how the young react? Observations like this are well worth keeping in your note book.

Audrey Lebedowich saw a pigeon fly into their chicken coop. "It would get along quite well with the chickens. It would sit on the roosts when it wanted to. After a week it flew away."

We're glad to hear that pigeons get along better with domestic fowl than they do with domestic cats.

\section{THE RATTLESNAKE ON THE}

\section{TRANS-CANADA HIGHWAY}

by Colette Isinger, age 9, Yellow Creek

In the summer of $1967 \mathrm{my}$ father, mother, brother and I went for a trip to Drumheller, Alberta.

Coming back home we drove on the Trans - Canada Highway. We were going quite fast when my father noticed a snake on the highway. My dad backed the ear up to look at the snake. We found out it was a rattlesnake. We could hear it rattling a little bit. It was warming its body on the warm pavement. By and by some big trucks with double wheels ran over the snake. Then it was dead.

\section{Letters and Notes}

\section{SOME GULL OBSERVATIONS}

I have long admired the flight of gulls and riding a tractor affords many opportunities to observe them at close range. On breezy days they often come within 10 feet as they float, dip and wheel with scarcely a wing-beat. It seems to me that there has been a shift in population. Years ago, the Franklin's Gull was predominant with only the odd Ring-billed

\section{A RUFFED GROUSE}

by Stella Holinaty, age 11, Yellow Creek

One day as our father was taking us to school we saw a Ruffed Grouse. The grouse was badly hurt. We picked him up and looked at him. He was grayish in color. He ruffed out his tufts on the side of his neck and then I knew it was a Ruffed Grouse. Dad said that we should take it to school but before we got to school it was dead.

\section{JUNIORS EXPRESS THEMSELVES ABOUT THEIR SECTION}

Two Juniors heard from, Wayne Renaud and Mary Gilles, both like the idea of contests. Wayne thinks nature stories would fit nicely into the Newsletter but he wants factual information as well and thinks that "at the age of 16 juniors should start contributing to the senior section. By that age they should be experienced enough to gain a say in the adult section. After all Ornithology is one profession where amateurs can contribute a lot."

Wayne and Mary would both like to see nature hobbies written up complete with illustrations.

As for Wayne he reads the entire Blue Jay. He finds it breaks the monotony of reading guide books.

Thanks for letting us hear from you. Any more suggestions?

Send comments about, suggestions for, and contributions to this section to: Mrs. Joyce Deutscher, 7200 6th Ave., Regina.
Gull among them. Now I seldom see large groups of Franklin's, but the Ring-bill is in evidence almost every diay all summer, singly or in groups of up to 50. They don't wander like Franklin's but may stay all day in one field following the tractor or just sitting on the ground.

It isn't unusual to see a gull, particularly Franklin's, with only one leg showing beneath the tail coverts. For 
a long time I assumed that these were birds that had lost one leg. Imagine my surprise one day to see a Ring-bill without any legs showing! I watched it for several hours as I drove, sometimes at less than 10 feet. The bird was healthy, its plumage immaculate. There was no sign of stumps, not a feather out of place underneath the body, only slight bulges where the thighs should be. Eventually the truth came out. I was watching the "legless gull" when suddenly it stooped to pick up an insect. It lowered two perfectly good legs as it hovered, and then tucked them forward into the belly feathers and out of sight. Even from close range there was no sign of a leg or foot, only the slight bulge in the plumage. I wondered why one individual would carry its legs forward when the normal posture is back under the tail, very much in view.

A year later came the pay-off. A "one-legged" Ring-bill hovered overhead, then wheeled down wind, swung and came directly toward me. As I watched, it lowered its "good" leg, then produced the other leg from somewhere and vigorously scratched its foot in flight. As it went by me it again became a "one-legged gull."

I was so astonished that I stopped the tractor and, as if to oblige, the bird repeated the manoeuvre exactly. It swung away and again as it approached up wind, down went the visible leg and it was then scratched thoroughly with the other one. Then both legs were retracted, one backwards under the tail, where it was visible, and the other out of sight in the plumage. Has anyone an explanation for this variation in leg posture? -Frank McLeod, Dilke.

Editor's Note: Gulls and some other birds are able to hold their feet in either a forward or a backward position when in flight. In the forward position the feet can be tucked into the belly feathers and this possibly helps keep them warm. The feet are presumably tucked into the feathers on cold days or during extended flight. In this connection see the notes on Sandhill Cranes tucking their feet for- ward (Blue Jay, 23:121, 24:47). Gulls, when searching for food by hovering above the ground, may keep one foot out for balance or in preparation for landing. There may, of course, be other explanations for this interesting behaviour. Grebes, while resting on the water, often keep one foot on their back, tucked beneath a wing. They accomplish this by means of a remarkable flexure of the leg, first shaking the foot or holding it aloft, presumably to dry it, then slipping it beneath the wing. It is not known why they do this, but it is apparently done in all seasons. Possibly this is a means of resting the limb. Many birds customarily stand on one leg in evident comfort. It seems reasonable to suppose that folding one or both feet forward when in flight may be simply for comfort.

\section{ATTRACTING HUMMINGBIRDS}

All wild birds tend to settle in an area in direct proportion to the amount of food available to support them, and normally they keep out competitors of their own kind. We have attracted hummingbirds to our area by artificially increasing the food supply, until we now are feeding more than 50 pairs of hummingbirds, augmented by their offspring at the end of the nesting season.

We began with the provision of both wild and cultivated flowers in our garden. Flowering wild currant, fuchsia, columbine, honeysuckle, canterbury bell, foxglove, montbresia and huckleberry are very acceptable and enticing to hummingbirds. E. W. Van Blaricom would add blue salvia, scarlet runner bean and monarda, and prairie friends would add the delphinium.

Then we added 10 feeding stations, placed in likely locations adjacent to flowers on stakes several feet above the ground. On the end of each feeder a plastic flower is attached, preferably red. Once they are accustomed to these feeders, they will also come to yellow flowers. The feeders vary in size, but each is a bottle with a rubber cork pierced through with a glass 
tube. Such corks with glass tubes are available as hamster feeders or hummingbird feeders. Glass tubes are preferred to metal tubes. The right syrup is one cup of sugar to four cups of water, boiled for five minutes. Unboiled syrup will not keep and crystallizes in the feeders, plugging the tubes. The bottles must be kept clean and filled or changed at intervals. The bottles must always have food in them, since hummingbirds have a high state of metabolism and feed about every 15 minutes from dawn to dark. To break off or reduce the program would be to sentence the young birds to death, since the number of rests established will be on the basis of the amnunt of food originally available, and the young consume more than their weight of food every day. We have used more than 150 pounds of sugar in one season.

An observant bird fancier will be amply rewarded for his efforts with these little winged jewels. While I don't recommend a program of the size that ours has become, it has been fascinating and educational for our family and friends.-Mrs. Myla Watson, Sechelt, B.C.

Editors' Note: Sechelt is on the coast of Georgia Strait, just north of Vancouver. E. W. Van Blaricom read Mrs. Watson's letter to the Central Okanagan Naturalists' Club on November 7, 1967.

\section{WINTER BIRDING IN ALABAMA}

Like the birds, I flew from Saskatoon to Alabama last winter, arriving on December 22, 1966. After two or three days of rain following my arrival, the sun came out bright and warm at seven o'clock in the morning. Instantly the yard burst into colour -not of flowers, but of birds of every hue. Fascinated, my eyes picked out cardinals, blue jays, mockingbirds, towhees, juncos, red-bellied woodpeckers and numerous others that I was unable to identify. What a sight for bird-hungry eyes!. Then with binoculars and a good bird book, a summer tanager, a song sparrow, and a savannah sparrow were sighted. And imagine my delight when our dear Canada bird, the white-throated sparrow, joined the throng. But where were the robins? That question was soon answered when I took a walk along an open field, the ground was alive with robins. But in spite of feeders and berries on the bushes they would not come near the house. One day I saw numerous red-breasted birds in the trees and on the telephone wires that looked unfamiliar to me, but when they took flight and soared upward they wore lost against the blue sky. Bluebirds, I shouted, scores and scores of bluebirds. Then there was a tawny flash as a brown thrasher flew to cover. We scattered seeds in the garden, and lovely mobile colors sprang up everywhere. The cardinals and blue jays looked especially beautiful among the yellow daffodils.

Just a word about the pecking order. Although all the birds were very amiable, the ecclesiastical cardinal seems to be the "boss man" here in Alabama.-Mrs. R. E. Swain, 906 9th Ave., Saskatoon.

\section{AN UNUSUAL ROBIN NEST}

In checking 1967 nesting records for the Crescent Beach area, North Surrey, B.C., I came across a rather unusual nest of an American Robin, dated April 28. This nest was in a red cedar tree, approximately eight feet from the trunk of the tree and at the end of a limb, and some 10 feet from the ground. Besides the conventional nesting materials such as coarse and fine grasses and mud, the bird used the following rather bizarre items: soda straws (waxed drinking type), tissue paper, one chewing gum wrapper, various kinds of white and brown string, nylon fishing line, bits of orange-coloured onion sacking, dried bedstraw, and a piece of cellophane! All other nests from this area were of the more usual type.-Al Grass, 5666 Rumble St., Burnaby 1, B.C. 


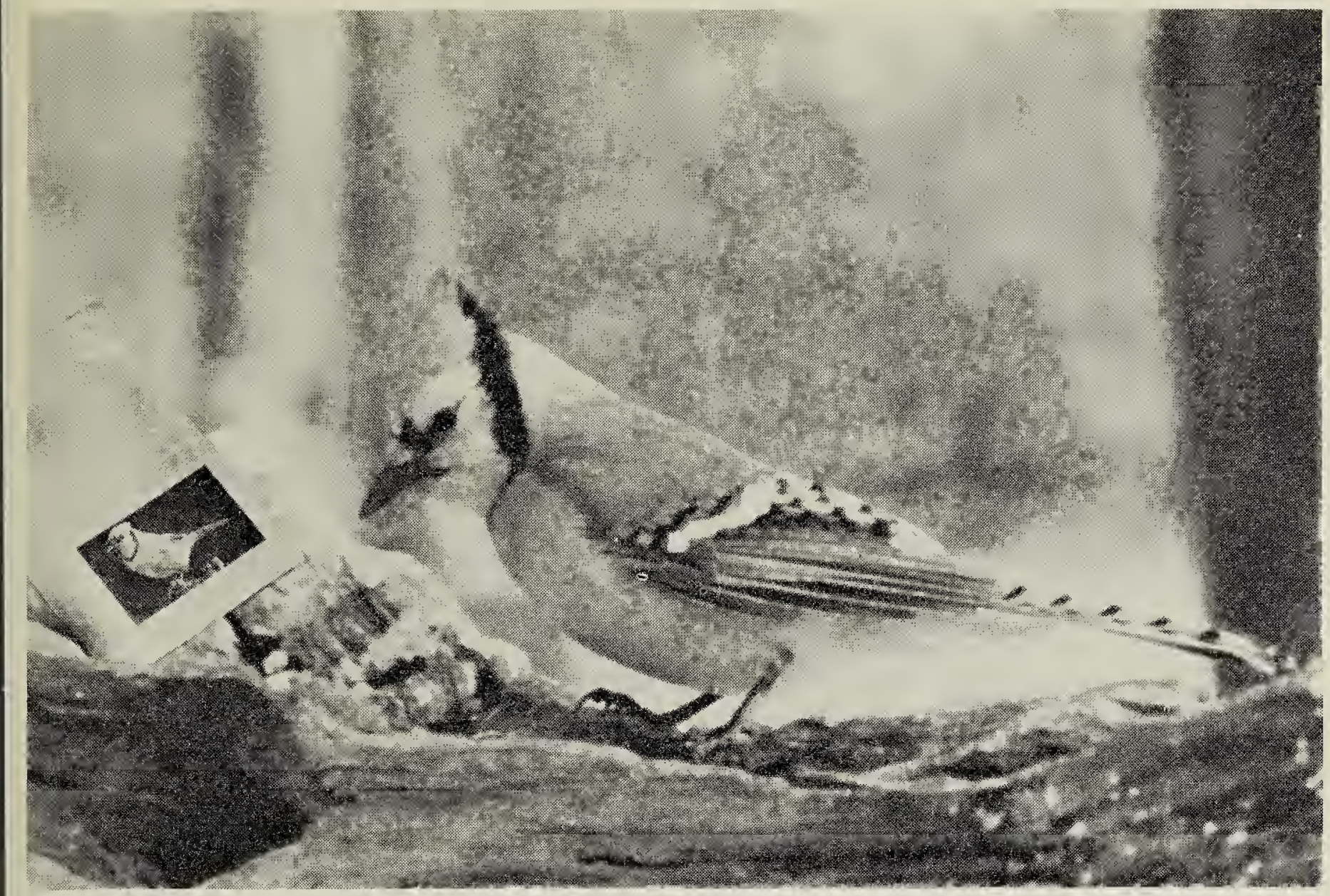

My regular winter customer looks at his picture printed in a recent issue of the Blue Jay.-F. W. Kent, 302 Richards St., Iowa City, Iowa.

\section{ENCOUNTER WITH A GOLDEN EAGLE}

On December 17, 1966, Bruce and Robert Bessant and I were walking down the edge of a high shale bank which drops into the Souris River when suddenly an extremely large and dark bird flew out from the edge of the river bank below us. By the time I spotted the bird it had flown a considerable distance down the river, flying very close to the surface of the ice. After flying between a quarter and a half mile away it perched in a birch tree which was overhanging the river. We had a pair of $6 \times 30$ binoculars but were unable to identify it at that distance. We decided to try to get closer to it and started down the bank. On the way down I found the spot where the bird had been sitting under a stunted oak tree. It had evidently been sitting there for some time, for the snow was well flattened down and had started to melt. Droppings at the site were very watery-looking and greenish-yellow, and had stained much of the snow. When we reached the river, the bird flew out of the birch tree and landed on the snow-covered ice, just as if it had caught something. It sat in this position for a few minutes and appeared to be pecking at something at its feet. We were close enough to tell by its size that it was an eagle, but we were still not sure of the species.

Continuing on down the river towards the eagle, we worked our way through an island in the river which was thickly covered with young willows. When we came out of the willows, the eagle was nowhere in sight. I continued down the edge of the river with my two young friends close behind. When I reached the spot on the river where the eagle had been sitting, I was amazed to see it sitting up on the edge of the river bank on a deer trail. It made no move to fly away and we were so close we could see the golden flecks on the back of its neck. We could also see that its legs were feathered almost to the toes. We ap- 
proached it and it then ran into the bush, but still would not fly. We walked to within eight or 10 feet of it several times to try to make it fly, but it would only walk away from us. In fact, it threatened us when we approached too close. There was no sign of a wound, but it appeared to be sick for its feathers were very rough and untidy. It also appeared to be hungry. We decided it would be best to leave it alone for we did not have anything with which to handle it. We went back onto the river and measured where the eagle's wing tips had touched the snow just before it landed. From two such spots measured, I judged that its wingspread was between six and seven feet. There was no sign that it had been feeding on anything at this site. We then left the area. I returned with a camera and with a friend on December 19, but we could not find the eagle. There were so many deer tracks that it was impossible to look for its trail.

We sighted a Golden Eagle which was in excellent shape in this same area in the spring of 1967 and in November 1967, Mr. A. Black of Brandon and I saw two Golden Eagles and one mature Bald Eagle soaring in the same general area.-E. J. Bud White, 410 Laurence Cres., Brandon, Man.

\section{UNUSUAL EAGLE BEHAVIOUR}

During a severe spell of weather in January, 1967, a white pigeon wearing a band appeared on my farm, roosting in the garage. I caught and fed it several times and it remained for a couple of weeks. It would not stay in the barn or associate with the barn pigeons, and it was not able to forage as they did. If I hadn't put out feed on the roof it would probably have starved.

One afternoon my wife called me to see a large black bird flying through the barn yard. Looking out the window I saw a Golden Eagle perched in the top of a large evergreen about 70 yards from the house. I have never seen an eagle this close to buildings before. After about a minute the eagle launched itself and flew directly toward the house at high speed. It was thrilling to see such a large bird approaching headlong! It held the direct course until it disappeared from our view above the roof of the low verandah. There was no sound on the roof and when I went out there was no sign of the eagle or the pigeon. I believe that the pigeon was the target of the eagle's bold flight for it was not seen again. I assume that hunger made the eagle extra bold and that it attacked the pigeon as it sat on the verandah roof. I have no way of knowing if the pigeon was picked off the roof or if it was captured in flight, but the former seems more likely.Frank McLeod, Dilke.

\section{PREDATORS}

It seems to me that there are too many people writing to the Blue Jay in support of predators. While predators are all right to clean up a little surplus, when there is no surplus I feel that there should not be any predators either. Last year there were only six Gray Partridges left here out of 30 which started the winter, and then one of the falcons came around and I did not see another partridge until fall, when one family of 15 showed up. This was probably a late hatch after I had shot the crows and magpies! Then a couple of weeks ago a Great Horned Owl took 10 of them in a week. While it is true that birds of prey take many rodents in the summer months, in the winter they have to catch rabbits and partridges, or die, and since there is a shortage of these latter species, why protect predators?

Does anybody know if the Western Kingbird is prone to nesting problems? Last year I checked two nests after they were abandoned suddenly and found two dead young in one and one bird dead in the other, with its toe tangled in the wool lining. This year there were three pairs around the buildings, and then all of a sudden before the first of Augusit, they all vanished.-Richard Bothner, Beechy. 


\section{BIRD NOTES FROM OXBOW}

I have been intending for some time to write you a note in regard to song birds trying to rid their nests of cowbird eggs. This past summer, a female Brewer's Blackbird covered over a cowbird's egg along with one of her own, and then apparently deserted the nest. A nest has been built in that young evergreen each spring for years, but a nest has never been successful there, although several in the other trees in the same row of evergreens are always lucky!

Birds are scarce this winter at Oxbow. We have had a chickadee only twice, and today (January 9) was his first trip to the feeder. There is the odd woodpecker in the bluffs, but none are coming to the feed tray as they usually do. One flock of Bohemian Waxwings was here on a miserable day in December. We have seen Snow Bunting's and two Snowy Owls, and a few Gray Partridges and very few Sharptails. Female pheasants have been seen four times, and friends have seen a male - we hope the weather doesn't kill them, for they are scarce here. Horned Larks are appearing now, although the e were none in December, but there are no redpolls.

Occasionally we hear a Great Horned Owl, so we hope we shall have a family for Dr. Stuart Houston to band in 1968. He did band a pair here in 1966 and reported the recovery of one of them in the United States, a long way from here.-Mrs. Hazel Paton, Oxbow.

\section{CHRISTMAS BIRD COUNT}

WETASKIWIN, Alberta, Dec. 25; about the farmyard; temp. $18^{\circ}$; no wind; overcast in afternoon; 4 species, 59 individuals. Downy Woodpecker, 2; Black-billed Magpie, 3; Black-capped Chickadee, 4; House Sparrow, 50. (Add: Ruffed Grouse, 1, Dec. 26; Blue Jay, 4, Dec. 26; Bohemian Waxwing, 3, Dec. 27; Evening Grosbeak, 8, Dec. 28).-Fred H. Pegg.

\section{RE PLANT SECTION}

I will not be able to make regular contributions to the Plant Section of the Blue Jay for the next two years. I am beginning a programme towards a Ph.D. in weed science in Winnipeg this January. I plan to take sor: a classes and do some instructing from January to April, work in Swift Current for the summer months and then move with my family to Winnipeg for the next two years.-Keith F. Best, Box 1030, Swift Current.

\section{RECORD LILY}

Mrs. Oliver Olafson, Box 88, Tantallon in "Garden Exchange" in the Western Producer, August 10, 1967 reports seeing a Prairie Lily with nine flowers and one bud. She is anxious to know if this is a record. - Bill Richards, 233 Taylor St. E., Saskatoon.

\section{PRE-PUBLICATION PRICE}

Dr. B. Boivin's Flora of the Prairie Provinces is being printed by photooffset in Ann Arbor. It will be in four parts, and the first part of 202 pages should be available soon. All four parts should be out in 1968 .

The subscription or pre-publication price is only $\$ 10$, plus tax, for the set. If you send in your money now we will send you the first part and the three remaining parts will be sent direct from Ottawa as soon as they are available. A higher post-publication price will go into effect as soon as all four parts are available. - The Blue Jay Bookshop, Box 1121, Regina, Sask.

\section{USED BOOKS WANTED}

Do you have books on birds, plants, minerals, or any natural history or natural science subject for sale? Please send your list for appraisal to W. W. McGregor, 59 Divadale Drive, Toronto 12, Ontario. 